Pacific Journal of 


\title{
A LOCAL ESTIMATE FOR TYPICALLY REAL FUNCTIONS
}

\author{
George B. Leeman, JR.
}

In this paper it is shown that for each typically real function $f(z)=z+\sum_{n=2}^{\infty} a_{n} z^{n}$ the local estimate $n-a_{n} \leqq$ $(1 / 6) n\left(n^{2}-1\right)\left(2-a_{2}\right)$ holds, $n=2,3, \cdots$. The constant $(1 / 6) n\left(n^{2}-1\right)$ is best possible.

Bombieri [1] proved the existence of constants $\gamma_{n}$ such that for each function $f(z)=z+\sum_{n=2}^{\infty} a_{n} z^{n}$ analytic and univalent in the unit disk $D$,

$$
\left|\operatorname{Re}\left(n-a_{n}\right)\right| \leqq \gamma_{n} \operatorname{Re}\left(2-a_{2}\right), \quad n=2,3, \cdots .
$$

Hummel [2] showed that if in addition $f$ maps $D$ onto a domain starlike with respect to the origin, then $\left|n-a_{n}\right| \leqq \gamma_{n}\left|2-a_{2}\right|$ for the value

$$
\gamma_{n}=n\left(n^{2}-1\right) / 6
$$

furthermore, this choice of $\gamma_{n}$ is best possible. In this paper we shall show that (2) is also the best possible constant in (1) for the collection of univalent functions with real coefficients. More generally, we answer this question for the set $T$ of typically real functions.

Definition 1. A function $f(z)=z+\sum_{n=2}^{\infty} a_{n} z^{n}$ analytic in $D$ is said to be typically real provided $f(z)$ is real if and only if $z$ is real.

The class $T$ was introduced by Rogosinski [5], [6]. Among other things he showed that if $f(z)=z+\sum_{n=2}^{\infty} a_{n} z^{n} \in T$, then $a_{n}$ is real and $\left|a_{n}\right| \leqq n, n=2,3, \cdots$. Note that if $f(z)=z+\sum_{n=2}^{\infty} a_{n} z^{n}$ is univalent in $D$ and has real coefficients, then $f(\bar{z})=\overline{f(z)}$. From this fact it easily follows that $f \in T$.

We now introduce a family of polynomials $P_{n}(t)$ closely related to the Chebyshev polynomials of the second kind.

Definition 2. For each $n, n=1,2, \cdots$, set

$$
r=\left[\frac{n-1}{2}\right], \quad P_{n}(t)=\sum_{k=0}^{r}(-1)^{k}\left(\begin{array}{c}
n-k-1 \\
k
\end{array}\right) t^{n-2 k-1},
$$

where $t$ is real.

Definition 3. Let $c_{n}$ be the largest critical point of $P_{n}(t)$, $n=3,4, \cdots$. 
To solve our problem, we need the following properties of these polynomials:

Lemma 1. $P_{n}(2 \cos \theta)=\sin n \theta / \sin \theta$ for each $\theta \in[-\pi, \pi], \quad n=$ $1,2, \cdots$. (The righthand side is defined so as to be continuous at $\theta=0, \theta= \pm \pi$ ).

2. $P_{n}\left(c_{n}\right)=\min _{t \in[0,2]} P_{n}(t)$, and $P_{n}^{\prime}(t)$ is strictly increasing in $\left[c_{n}, \infty\right)$.

3. If $n \geqq 4$ is even, then $\left|P_{n}(t)\right| \leqq n|t| / 2$ for all $t \in[-2,2]$. Equality holds only for $t=0, t= \pm 2$.

4. $P_{n}^{\prime}(2)=\gamma_{n}, n=1,2, \cdots$.

Proof. The first three properties follow from Lemma 1 of [3]. To prove part 4, we observe that the derivative of the function $\theta \rightarrow \sin n \theta / \sin \theta$ exists at $\theta=0$, and we differentiate the identity in part 1 to arrive at

$$
\begin{aligned}
& P_{n}^{\prime}(2)=\lim _{\theta \rightarrow 0} \frac{\sin n \theta \cos \theta-n \sin \theta \cos n \theta}{2 \sin ^{3} \theta} \\
& =\lim _{\theta \rightarrow 0} \frac{\left(n \theta-n^{3} \theta^{3} / 6+\cdots\right)\left(1-\theta^{2} / 2+\cdots\right)-n\left(\theta-\theta^{3} / 6+\cdots\right)\left(1-n^{2} \theta^{2} / 2+\cdots\right)}{2 \theta^{3}+\cdots} \\
& \quad=\lim _{\theta \rightarrow 0} \frac{3 n\left(n^{2}-1\right) \theta^{3} / 3+O\left(\theta^{4}\right)}{2 \theta^{3}+O\left(\theta^{4}\right)}=\gamma_{n} .
\end{aligned}
$$

The proof of the lemma is now finished.

Let us remark that two interesting corollaries of the lemma are the combinatorial identities

$$
\begin{gathered}
\sum_{k=0}^{m-1}(-1)^{k}(m-k)\left(\begin{array}{c}
2 m-k \\
k
\end{array}\right) 4^{m-k}=\left(\begin{array}{c}
2 m+2 \\
3
\end{array}\right), \quad m=1,2, \cdots \\
\sum_{k=0}^{m-1}(-1)^{k}(2 m-2 k-1)\left(\begin{array}{c}
2 m-k-1 \\
k
\end{array}\right) 4^{m-k-1}=\left(\begin{array}{c}
2 m+1 \\
3
\end{array}\right), \\
m=1,2, \cdots,
\end{gathered}
$$

which result from part 4 and Definition 2.

We can now prove our main result.

THEOREM. If $f(z)=z+\sum_{n=2}^{\infty} a_{n} z^{n} \in T$, then $n-a_{n} \leqq \gamma_{n}\left(2-a_{2}\right)$, $n=2,3, \cdots$, where $\gamma_{n}$ is given by (2). Equality can hold only when $f(z)=z /(1-z)^{2}$.

Proof. Let $a_{2}=x$, and fix $n>2$; we seek the smallest $t=$ $t(n)>0$ such that

$$
n-a_{n}-t(2-x) \leqq 0
$$


If $n$ is odd, we may assume $x \geqq 0$, since $-f(-z) \in T$. Apply Theorem 2 of [3] to obtain the sharp inequalities

$$
t x-a_{n} \leqq\left\{\begin{array}{l}
t c_{n}-P_{n}\left(c_{n}\right) \text { if } 0 \leqq x \leqq c_{n}, \\
t x-P_{n}(x) \text { if } c_{n} \leqq x \leqq 2
\end{array}\right.
$$

where equality can hold when $c_{n} \leqq x \leqq 2$ only for the function

$$
f(z)=z /\left(1-x z+z^{2}\right) .
$$

To satisfy (3) we must have

$$
t \geqq \max \left(\frac{n-P_{n}\left(c_{n}\right)}{2-c_{n}}, \max _{c_{n} \leqq x \leqq 2} \frac{n-P_{n}(x)}{2-x}\right)=\max _{c_{n} \leqq x \leqq 2} \frac{P_{n}(2)-P_{n}(x)}{2-x},
$$

by (4) and part 1 of the lemma. Using parts 2 and 4 and the meanvalue theorem, we conclude that $t \geqq P_{n}^{\prime}(2)=\gamma_{n}$; hence $t=\gamma_{n}$ is the smallest constant for which (3) holds. Furthermore, strict inequality holds in (3) unless $x=2$, that is, $f(z)=z /(1-z)^{2}$, by (5).

Next let $n$ be even, and put $F_{n}(t)=\left(P_{n}(t)+n\right) /(t+2), 0 \leqq t \leqq$ 2. By part 2 of the lemma $F_{n}$ attains its minimum at only one point $r_{n}$, with $c_{n} \leqq r_{n}<2$. Again Theorem 2 of [3] gives

$$
t x-a_{n} \leqq \begin{cases}t x+n-(x+2) F_{n}\left(r_{n}\right) & \text { if }-2 \leqq x \leqq r_{n} \\ t x-P_{n}(x) & \text { if } r_{n} \leqq x \leqq 2\end{cases}
$$

with equality for the case $r_{n} \leqq x \leqq 2$ only when $f$ is as in (5). Hence

$$
t \geqq \max _{-2 \leqq x \leqq r_{n}} \frac{2 n-(x+2) F_{n}\left(r_{n}\right)}{2-x}, t \geqq \max _{r_{n} \leqq x \leqq 2} \frac{n-P_{n}(x)}{2-x} .
$$

Now it follows from the definition of $F_{n}$, part 3 of the lemma, and direct algebraic manipulations that the maximum of the first term in (6) occurs at $x=r_{n}$ only. Consequently, as earlier we get $t \geqq$ $P_{n}^{\prime}(2)=\gamma_{n}$, and the rest of the argument proceeds as before. The proof of the theorem is thus complete.

COROLlARY. If $f(z)=z+\sum_{n=2}^{\infty} a_{n} z^{n} \in T$, then $n-\left|a_{n}\right| \leqq \gamma_{n}\left(2-\left|a_{2}\right|\right)$, where $\gamma_{n}$ is given by (2). Equality holds only for $f(z)=z /(1 \pm z)^{2}$.

Proof. By substituting $-f(-z)$ for $f(z)$ if necessary, we may assume that $a_{2} \geqq 0$. Then the theorem yields

$$
n-\left|a_{n}\right| \leqq n-a_{n} \leqq \gamma_{n}\left(2-a_{2}\right)=\gamma_{n}\left(2-\left|a_{2}\right|\right),
$$

with equality only if $f(z)$ or $-f(-z)$ is the function $z \rightarrow z /(1-z)^{2}$.

In conclusion, we show that the statement of our theorem is in 
general false if $T$ is replaced by the class of normalized univalent functions. To produce a counterexample we employ the theory of Löwner [4], which says in particular that if $K$ is a piecewise continuous function from $[0, \infty)$ into the unit circle $\partial D$, then there exists a univalent function $f(z)=z+\sum_{n=2}^{\infty} a_{n} z^{n}$ such that

$$
a_{2}=2 \int_{0}^{\infty} e^{-t} K(t) d t, a_{3}=a_{2}^{2}-\int_{0}^{\infty} e^{-2 t} K(t)^{2} d t
$$

We set

$$
K(t)= \begin{cases}1 & \text { if } 0 \leqq t \leqq \log 2, \\ (1+\sqrt{3} i) / 2 & \text { if } \log 2<t<\infty,\end{cases}
$$

and find from (7) that $a_{2}=(3+\sqrt{3} i) / 2, a_{3}=(5+11 \sqrt{3} i) / 8$, and $\operatorname{Re}\left(3-a_{3}\right)>4 \operatorname{Re}\left(2-a_{2}\right)$.

\section{REFERENCES}

1. E. Bombieri, Sull'integrazione approssimata dell'equazione differenziale di Löwner e le sue applicazioni alla teoria delle funzioni univalenti, Thesis, Università di Milano, Milano, 1963.

2. J. A. Hummel, The coefficients of starlike functions, Proc. Amer. Math. Soc., 22 (1969), 311-315.

3. G. B. Leeman, The constrained coefficient problem for typically real functions, Trans. Amer. Math. Soc., 186 (1973), 177-189.

4. K. Löwner, Untersuchungen über schlichte konforme Abbildungen des Einheitskreises, I., Math. Ann., 89 (1923), 103-121.

5. W. Rogosinski, Über positive harmonische Sinusentwicklungen, Jber. Deutsch. Math.-Verein., 40 (1931), 33-35.

6. - Über positive harmonische Entwicklungen und typisch-reelle Potenzreihen, Math. Z., 35 (1932), 93-121.

Received June 29, 1973.

IBM Thomas J. Watson Research Center 


\section{PACIFIC JOURNAL OF MATHEMATICS}

EDITORS

RICHARD ARens (Managing Editor)

University of California

Los Angeles, California 90024

\section{R. A. Beaumont}

University of Washington

Seattle. Washington 98105

\section{J. DugundjI}

Department of Mathematics University of Southern California Los Angeles, California 90007

D. Gilbarg and J. Milgram

Stanford University

Stanford. California 94305

\section{ASSOCIATE EDITORS}
E. F. BECKENBACH
B. H. NEUMANN
F. WOLF
K. Yoshida

\section{SUPPORTING INSTITUTIONS}

\author{
UNIVERSITY OF BRITISH COLUMBIA \\ CALIFORNIA INSTITUTE OF TECHNOLOGY \\ UNIVERSITY OF CALIFORNIA \\ MONTANA STATE UNIVERSITY \\ UNIVERSITY OF NEVADA \\ NEW MEXICO STATE UNIVERSITY \\ OREGON STATE UNIVERSITY \\ UNIVERSITY OF OREGON \\ OSAKA UNIVERSITY
}

\author{
UNIVERSITY OF SOUTHERN CALIFORNIA \\ STANFORD UNIVERSITY \\ UNIVERSITY OF TOKYO \\ UNIVERSITY OF UTAH \\ WASHINGTON STATE UNIVERSITY \\ UNIVERSITY OF WASHINGTON

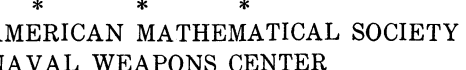

The Supporting Institutions listed above contribute to the cost of publication of this Journal, but they are not owners or publishers and have no responsibility for its content or policies.

Mathematical papers intended for publication in the Pacific Journal of Mathematics should be in typed form or offset-reproduced, (not dittoed), double spaced with large margins. Underline Greek letters in red, German in green, and script in blue. The first paragraph or two must be capable of being used separately as a synopsis of the entire paper. Items of the bibliography should not be cited there unless absolutely necessary, in which case they must be identified by author and Journal, rather than by item number. Manuscripts, in duplicate if possible, may be sent to any one of the four editors. Please classify according to the scheme of Math. Rev. Index to Vol. 39. All other communications to the editors should be addressed to the managing editor, or Elaine Barth, University of California, Los Angeles, California, 90024.

100 reprints are provided free for each article, only if page charges have been substantially paid Additional copies may be obtained at cost in multiples of 50 .

The Pacific of Journal Mathematics is issued monthly as of January 1966. Regular subscription rate: $\$ 72.00$ a year (6 Vols., 12 issues). Special rate: $\$ 36.00$ a year to individual members of supporting institutions.

Subscriptions, orders for back numbers, and changes of address should be sent to Pacific Journal of Mathematics, 103 Highland Boulevard, Berkeley, California, 94708.

\section{PUBLISHED BY PACIFIC JOURNAL OF MATHEMATICS, A NON-PROFIT CORPORATION}

Printed at Kokusai Bunken Insatsusha (International Academic Printing Co., Ltd.), 270, 3-chome Totsuka-cho. Shinjuku-ku, Tokyo 160. Japan.

Copyright (C) 1973 by Pacific Journal of Mathematics Manufactured and first issued in Japan 


\section{Pacific Journal of Mathematics}

\section{Vol. 52, No. $2 \quad$ February, 1974}

Harm Bart, Spectral properties of locally holomorphic vector-valued functions .....

J. Adrian (John) Bondy and Robert Louis Hemminger, Reconstructing infinite

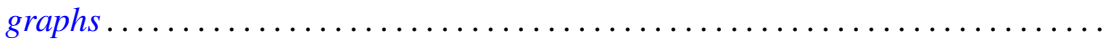

Bryan Edmund Cain and Richard J. Tondra, Biholomorphic approximation of planar

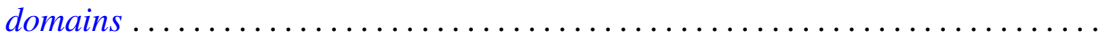

Richard Carey and Joel David Pincus, Eigenvalues of seminormal operators,

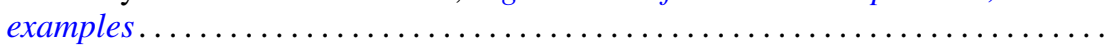

Tyrone Duncan, Absolute continuity for abstract Wiener spaces . . . . . . . . . . . . Joe Wayne Fisher and Louis Halle Rowen, An embedding of semiprime

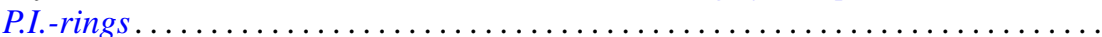

Andrew S. Geue, Precompact and collectively semi-precompact sets of semi-precompact continuous linear operators. . . . . . . . . . . . . . . .

Charles Lemuel Hagopian, Locally homeomorphic $\lambda$ connected plane continua ..... . Darald Joe Hartfiel, A study of convex sets of stochastic matrices induced by

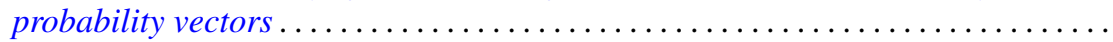

Yasunori Ishibashi, Some remarks on high order derivations $\ldots \ldots \ldots \ldots \ldots \ldots \ldots$ Donald Gordon James, Orthogonal groups of dyadic unimodular quadratic forms.

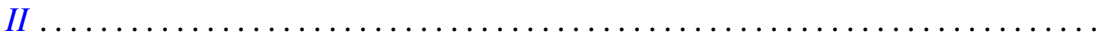

Geoffrey Thomas Jones, Projective pseudo-complemented semilattices . . . . . . . . . Darrell Conley Kent, Kelly Denis McKennon, G. Richardson and M. Schroder,

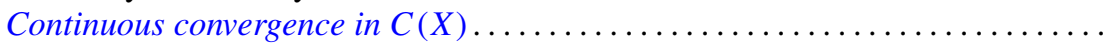

J. J. Koliha, Some convergence theorems in Banach algebras ...

Tsang Hai Kuo, Projections in the spaces of bounded linear oper

George Berry Leeman, Jr., A local estimate for typically real functions . .

475

Andrew Guy Markoe, A characterization of normal analytic spaces by the

homological codimension of the structure sheaf .........

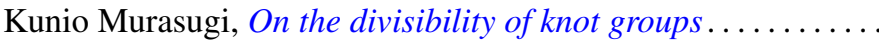

John Phillips, Perturbations of type I von Neumann algebras.

Billy E. Rhoades, Commutants of some quasi-Hausdorff matrices . .

David W. Roeder, Category theory applied to Pontryagin duality

Maxwell Alexander Rosenlicht, The nonminimality of the differential closure .

Peter Michael Rosenthal, On an inversion theorem for the general Mehler-Fock transform pair.

Alan Saleski, Stopping times for Bernoulli automorphisms

John Herman Scheuneman, Fundamental groups of compact complete locally affine complex surfaces. II. ........................

Vashishtha Narayan Singh, Reproducing kernels and operators with a cyclic vector. I. .

Peggy Strait, On the maximum and minimum of partial sums of random variables.

J. L. Brenner, Maximal ideals in the near ring of polynomials modulo 2 .

Ernst Gabor Straus, Remark on the preceding paper: "Ideals in near rings of polynomials over a field" ..........................

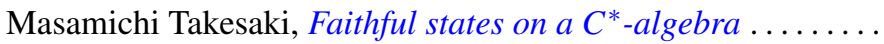

R. Michael Tanner, Some content maximizing properties of the regular simplex.

Andrew Bao-hwa Wang, An analogue of the Paley-Wiener theorem for certain

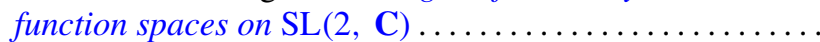

